\title{
Quality circles - a managerial response to the productivity problem
}

\author{
LJ. Smalley and H.J. Bocker \\ Department of Business Economics, University of South Africa, Pretoria and School for Business and \\ Economics, Wilfred Laurier University, Canada
}

The purpose of this article is to outline the development of the quality circle (QC) philosophy, its benefits and problem areas in which it can be applied, with reference to both theory and practical application. The QC organizational structure and special functions of the groups, individuals and committees involved in the process are also discussed. The groups com. prise the members, leaders, staff for technical support, facilitators (or coordinators), middle and top management, steering and advisory committees and union officials. A pro. cess flow diagram is used to represent a model of the QC flow for one complete operating cycle. It shows the various interdependencies of all the groups involved and how this system actually functions.

S. Afr. J. Bus. Mgmt. 1982, 13: 10-17

Die doel van hierdie artikel is om 'n oorsig te gee van die ontwikkeling van die kwaliteitsirkel-filosofie, asook die voordele daarvan en probleemgebiede waar dit toegepas kan word, met verwysing na sowel teorie as praktiese toepassing. Die organisasiestruktuur van kwaliteitsirkels, asook besondere funksies van die groepe individue en komitees wat by die proses betrokke is, word ook bespreek. Die groepe bestaan uit lede, leiers, tegniese ondersteuningspersoneel, koördineerders, middel- en topbestuur, bestuurs- en advieskomitees en vakbondamptenare. 'n Prosesvloeidiagram word gebruik om 'n model van die kwaliteitsirkel-vloei vir een volle bedryfsiklus uit te beeld. Dit toon die verskeie interafhanklikhede van alle groepe wat betrokke is, asook hoe die stelsel funksioneer.

S.Afr. Tydskr. Bedrytsl. 1982, 13: 10- 17

\footnotetext{
L.J. Smalky*

Senior Lecturer, Department of Business Economics, University of South Africa, P.O. Box 392, Pretoria 0001, Republic of South Africa

H.J. Bocker

Associate Professor, School for Business and Economics, Wilfred Laurier

University, Waterloo, Ontario, Canada

-To whom correspondence should be addressed

Accepted November 1981
}

\section{Introduction}

One of the most outstanding and fascinating developments over the past two decades on the international production scene has been the establishment and rapid growth of quality circles. This concept was developed as a direct response to poor quality and low productivity performance of the Japanese manufacturing industry during the early 1960 s.

Quality circles (QCs) comprise permanently established groups of volunteer workers (size: 4-20), commonly from the same work areas, with access to resources within the work system, having the support of management and trade unions (including technical assistance and training programmes) and meeting on a regular, scheduled basis during company time to discuss work-related problems specified by themselves. Each group will investigate causes of problems and recommend possible solutions to the decision-making body within their work system.

\section{The development of the quality circle movement}

According to Gregerman, ' the first controlled experiment designed to motivate the worker through active participation in the decision-making process, was conducted during the late 1920s and the early 1930s at Western Electric's Hawthorne Works in the United States of America (USA).

It was early in the 1950s when the Japanese invited Dr. W.E. Deming and Dr. J.M. Juran, two leading experts in the fields of statistics and quality control, to visit Japan. The purpose, to adapt and translate the USA concept (together with other Western European ideas) to conform to the Japanese philosophical, cultural and industrial background.

This objective was successfully achieved by Tokyo's Prof. K. Ishikawa, and the first Japanese quality circles were introduced in 1962, for foremen and engineers only. Figure 1 shows the development of the quality circle movement.

\section{The benefits of quality circles}

'The Japanese are coming.' Typically, Western reactions to statements like this vary between admiration, indifference, envy and fear. The Japanese threat to many Western companies, industrial sectors and/or whole economies is very real. 


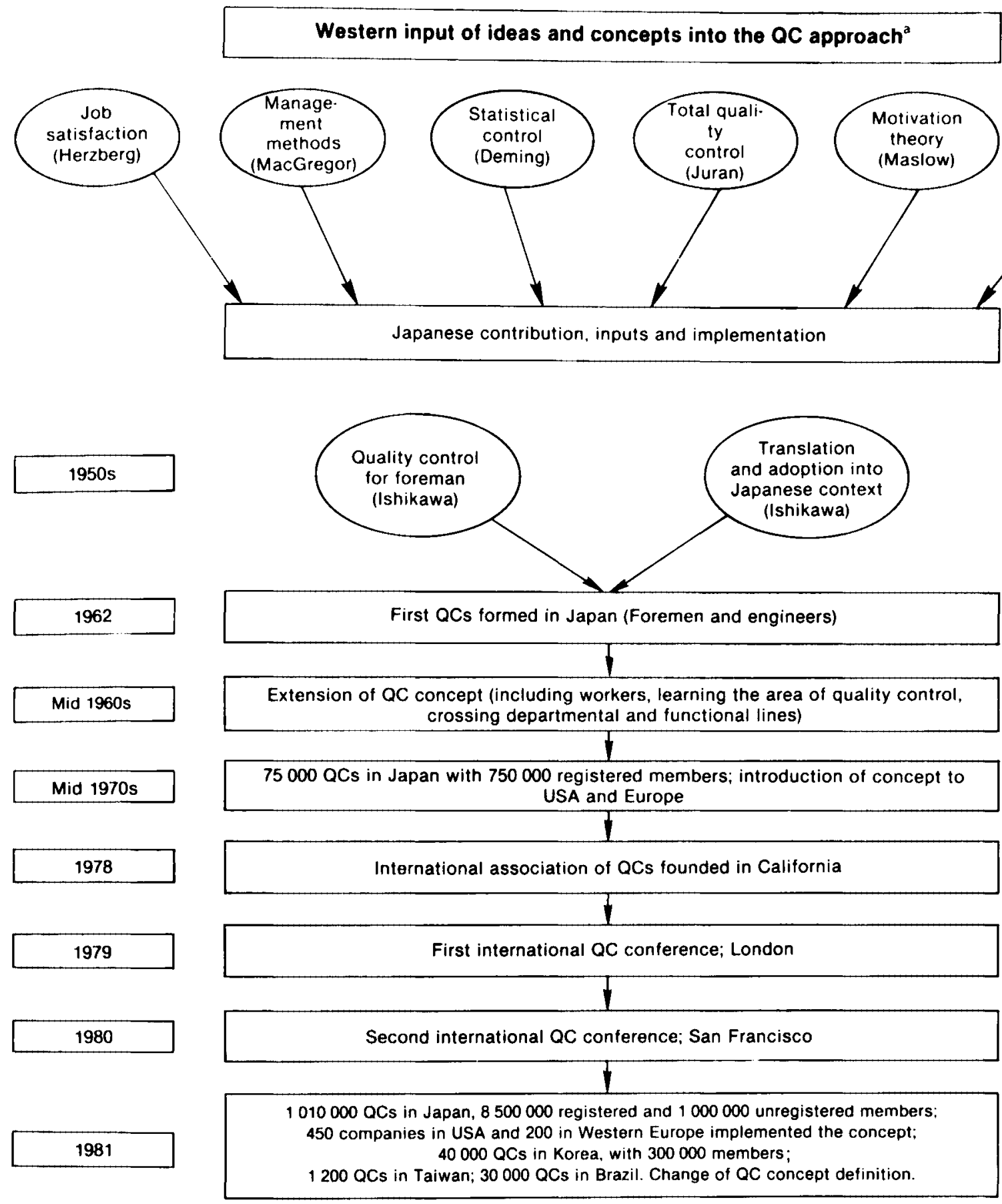

${ }^{\text {a }}$ Developed over almost a century

Figure 1 The development of the quality circle movement

In the late summer of 1980 the world-famous Swiss watch industry was forced to apply for government subsidies, support and protection. For the first time in history, Japanese watchmakers had out-performed the Swiss. At the same time, German motorcar manufacturers jointly announced a five-year plan calling for investments of gigantic proportions in order to compete with the Japanese.

World markets, especially the lucrative USA market, had in a short period become a Japanese preserve - leaving little room for higher-priced competitors whose products often were of inferior quality.

Meanwhile, at home, the Japanese silently enjoyed the benefits of their activities, well aware of the fact that the largest, most valuable, untapped resource is the human mind. And QCs were the invaluable aid in releasing this resource. Exploitation of this universal resource, combined with hard and efficient work, diligence, loyalty and willingness to learn and to participate, set free productive forces which indeed created a challenge to the rest of the Western world. Such results, however, did not come overnight and necessitated considerable changes.

The success of Japanese development, as shown in Table 1, seems to be almost unparalleled. An example of a development with far-reaching consequences can be observed in the area of 'thinking machines' or 'robots'. 
These robots, together with the modern microprocessor, perform the most complex and delicate production tasks at costs way below, and at speeds far exceeding the best worker or team. Their introduction paves the path for total automation of production processes at incredibly low unit costs. According to a recent article in the Pretoria News ${ }^{2}$ it was stated that for R 15 million, a fully automated and unmanned factory that would normally require $\mathbf{2 5 0}$ workers, could be made available to clients all over the world. The factory which manufactures lathes and machine tools is equipped with robots and controlled by six computers.

In another newspaper article ${ }^{3}$, Hitachi, a big name in the electronics industry, released a statement that within five years 'blue collar' workers will disappear entirely from their assembly lines. Factories will be manned only by clerical staff and maintenance technicians. The workforce, set free this way, is retained for higher-paid, more interesting software jobs. There are no unemployment problems. Careful consideration and close cooperation by workers is essential to introduce such changes and new developments without disruption - and here again the quality circle is a useful aid.

The above represent a few examples of Japanese success in the area of production and operations management. The conclusion to be drawn by managers should be obvious: the industries of the West (especially the USA) are in urgent need for revitalization, chiefly based on innovation. It should be borne in mind that technology is the product of man's creative thought, which is a 'free' resource. But systems and approaches are needed which can help to release and utilize this resource.

Table 1 Annual average per capita income in Japan between 1945 and 1981

\begin{tabular}{ll}
\hline Year & Annual average per capita income in US dollars \\
\hline 1945 & $\$ 20$ \\
1956 & $\$ 300$, approximately Third World level \\
1967 & $\$ 1000$, equalling Brazil \\
1970 & $\$ 1800$, after the first oil crisis \\
1974 & $\$ 3600$, after the second oil crisis \\
1979 & $\$ 10000$, after the third oil crisis, equal to the West \\
1981 & $\$ 12-13000$ (projection), overtaking many Western countries
\end{tabular}

A major factor in the Japanese success story is the QC approach, of which the following are some of the major benefits:

- Utilization of ideas and insights of workers regardless of level in organization.

- Promotion of creativity and problem-solving ability.

- Promotion of team work and team spirit.

- Commitment and motivation because of involvement in decision-making.

- Understanding of problems of colleagues in other functions and other departments through frequent contact, and cross-functional exposure and experience.

- No drastic change in existing systems required - can be introduced in stages.
Problem areas to which the quality circle approach has been applied

The American Society of Quality Control has established a typical distribution of the possible problem areas and percentages of quality circle activities. ${ }^{1, n .22}$ As can be seen from Table 2, the attention, previously focussed entirely on the quality aspect, has been diverted to a number of other areas such as efficiency, costs, morale, etc.

Table 2 Problem areas and percentages of QC ac. tivities

\begin{tabular}{lc}
\hline \multicolumn{1}{c}{ Problem Area } & Percentage of QC activity \\
\hline Quality & $22 \%$ \\
Efficiency & $12 \%$ \\
Costs & $11 \%$ \\
Morale & $10 \%$ \\
Equipment & $10 \%$ \\
Process control & $9 \%$ \\
Absenteeism & $8 \%$ \\
Safety & $4 \%$ \\
Learning $^{2}$ & $3 \%$ \\
Others $^{\mathrm{a}}$ & $11 \%$ \\
\hline
\end{tabular}

This includes other aspects relating to the productivity concept.

\section{The quality circle system, layout and organiza- tional structure}

The structure of a QC system can best be depicted in graphical form as represented by Figure 2 . The triangular shape is an indication of the increasing or decreasing importance/significance of the various groups involved as well as their contribution in terms of input. Of course, the presence and cooperation of all groups is an absolute necessity. No group is 'unimportant' and none could be omitted from the system without impairing the overall success.

The upper two groups (QC members and leaders) represent the area 'where the action is' (that is where acute problems will be attacked and solved). The remaining four groups, by contrast, play a more supportive role in a descending order of direct involvement in this process of problem-solving. In addition to the six groups involved, there are also two committees, a steering committee and an advisory committee. Union officials are also included to provide overall support and to make recommendations and suggestions whenever necessary.

Special functions of the groups, individuals and committees involved in the quality circle process

Quality circle members (group I)

Quality circle (QC) members are usually volunteer workers from the same problem-related area of the production process. Meetings are held during company time on a regular basis, at least once a week. Each meeting lasts for approximately one hour and comprises the following five sections:

- 5-minutes opening, introduction of new members, news of a general nature and organizational aspects;

- 5-minutes reviewing the previous week's activities;

- 25-minutes learning new skills and material; 


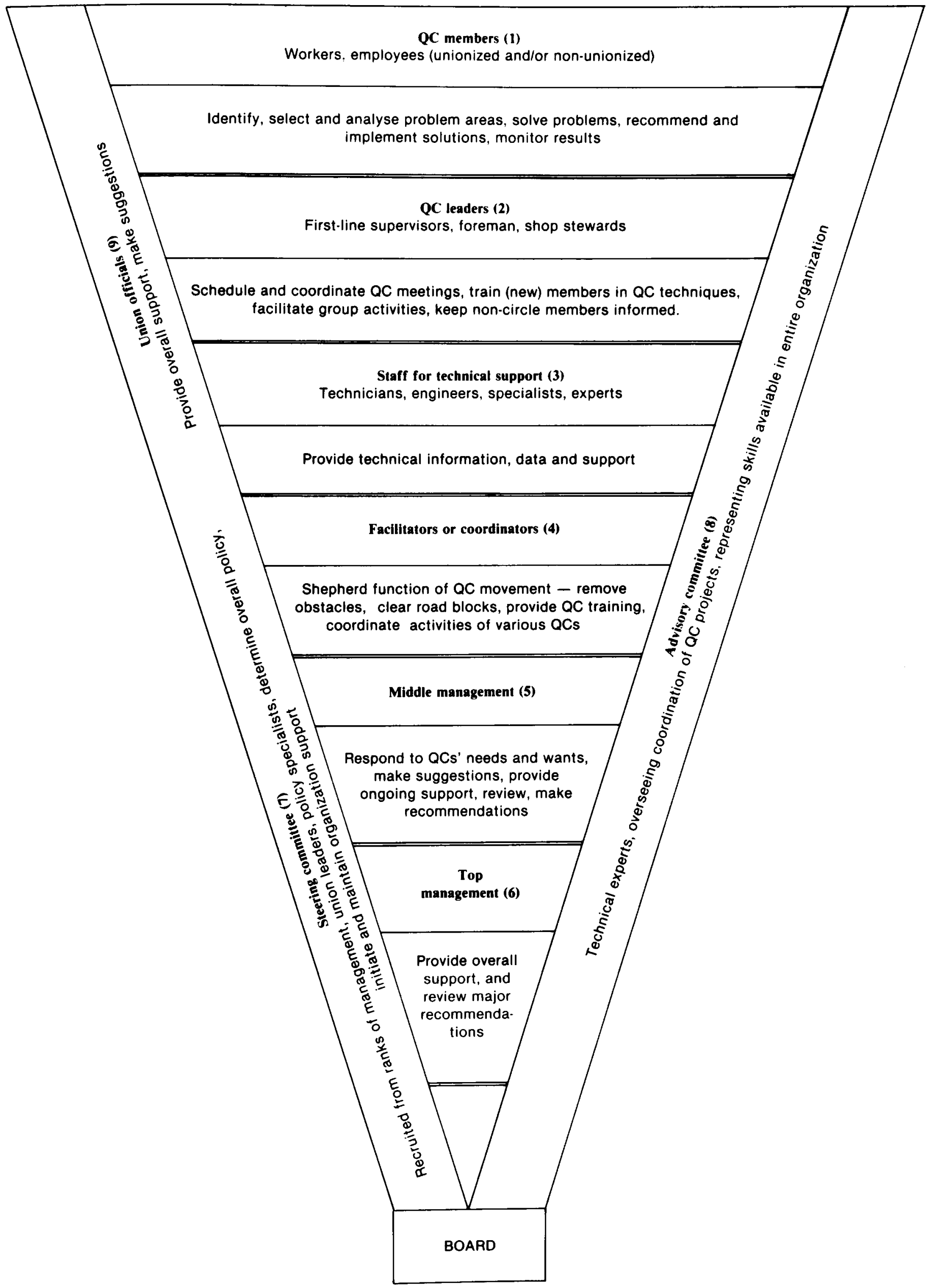

Figure 2 Quality circle organizational structure 
- 20-minutes applying new skills and knowledge to practical problems; and

- 5-minutes summary and review of what has been achieved.

Minutes are taken at each meeting and passed on to the QC leader, who, in turn, coordinates them with the agendas, schedules and activities of other QCs.

It should be noted that efforts and results are not related in a linear way. Typically $50 \%$ of total energy and effort might solve only $85 \%$ of the particular problem. The remaining $50 \%$ will contribute only marginally, by perhaps $10 \%$, to the total solution. The same is true when comparing one problem with another. The first might make a very substantial contribution to the department's or company's performance, the second almost none, for a given effort in both cases. Therefore, the QC should be trained in pareto analysis which would enable them to terminate a particular problem and move to another, because the benefits gained by continuing with the first one have become marginal. Solutions are presented by the QCs to middle management, and in cases where major recommendations are necessary, to top management. The results of brainstorming, analyses and calculations by members of the QCs have to be put together and presented with a certain minimum level of presentation skills. Ordinarily, this would include overhead projections, flip charts, histograms, frequency diagrams, graphs, logging check sheets, and pareto and value analysis. An advanced level of presentation would, in addition, make use of slides, films, various quality control charts, scattergrams, probability distributions, stratification, regression analysis, forecasting and other techniques.

\section{Quality circle leaders (group 2)}

In order to make decisions effective, the QC leader will make sure that they are taken by consensus. This facet is important since any transgression of this rule will tend to frustrate and alienate $\mathrm{QC}$ members, resulting in a possible QC breakup. The Japanese mentality, endowed with a lot of patience, is probably better suited for this purpose than its USA and Western European counterparts.

According to Nosow ${ }^{4}$, QC leaders need specialized training, including aspects such as participatory leadership as well as group process skills, QCs' responsibilities, organization and underlying principles, (for example, the axiomatic belief that the answers to the problems are unknown), data gathering, problem-solving skills, as well as certain techniques to win the cooperation of top management, unions and non-member workers.

The extent of the training will enable the QC leader to pass his or her skills on to the QC members. The initial training is rather basic but as it advances, the process of passing it on to the members also involves more complex procedures. This continuous subsequent learning process provides the basis for continuing group enthusiasm. Hutchins ${ }^{5}$ mentions that Western QC observers are often surprised to find that Japanese QC leaders are capable of applying high-level statistical techniques.

\section{Staff for technical support (group 3)}

This support group comprises the technical experts who may be called upon to assist the QC in problem-solving.
They may offer direct or indirect assistance and are often present at QC meetings.

\section{Facilitator or coordinator (group 4)}

Both terms, facilitator or coordinator are used synonymously. Small or medium-sized firms may have only one facilitator, larger ones having two or more, depending on the number of departments, divisions, the complexity and variety of problems to be solved. The role of the facilitator (or coordinator) is to coordinate several independent QCs and to be an organizational liaison between the QCs and management. The facilitator (or coordinator) will orientate company personnel, implement the programme, instruct and develop QC leaders, provide training and education for members and leaders, encourage non-members to join and, finally, monitor and measure results.

Facilitators, as well as QC leaders, have to be chosen carefully. They may come from any department, and should be well trained, be interested in people, have credible personalities and strongly believe in the programme. Without these attributes, they could easily be perceived as 'management patsies'. They should not be overloaded with other duties, which could prevent them from picking up all the subtle messages from the QC.

\section{Middle management (group 5)}

The middle-management level, after having been briefed about the QC concept, should respond to the wants and needs of the QCs. Managers can be approached directly by the QC leader, and/or, more indirectly, by the facilitator (or coordinator). Ongoing support by middle management is an indispensable component of QC success.

\section{Top management (group 6)}

The cooperation and total support of top management has to be secured prior to the formulation of the QC concept within the company. Consultants trying to introduce this concept should spend more than half of their total effort and time in persuading, convincing, or simply preparing the company's leaders for this new approach. Without their total acceptance any further steps are out of the question. If managers are antagonistic towards the programme, their subordinates will be demotivated and would not care, 'because the boss does not care'. Demotivation would also be the result when (top or middle) management rejects solutions without very carefully and thoroughly motivating their disagreement.

Yager ${ }^{6}$ mentions two approaches which have been successfully used to convince this group of the benefits to be obtained from the QC concept. The first approach centres on the fact that QCs do not require any drastic changes to other systems by which the firm operates. There are, for example, no new financial burdens or reward systems, job enrichment, rotation or enlargement, no rearrangement of factories, and, most important, no large capital investment.

The second approach is that the QC concept should be implemented on a pilot-line basis. This implies that a single QC is introduced and developed to its full potential. The risks are thus kept to an absolute minimum, since there is no grandiose company-wide scheme or 
'masterplan'. After the initial success, the QC programme can grow of its own accord.

In general, top management should be made aware of the basic differences in employee relations between Japan and most Western countries, in order to effectively apply this concept. The differences are briefly summarized in Table 3. The first four points are generally outside the area of influence and control of top management. The differing characteristics of points 5 to 12, however, can well be changed favourably toward Japanese conditions, particularly with the application of the QC concept.

Table 3 Basic differences between Japanese and Western employee backgrounds and relationships with management

\begin{tabular}{ll}
\hline \multicolumn{1}{c}{ Japan } & \multicolumn{1}{c}{ Western countries } \\
\hline $\begin{array}{l}\text { 1. Homogeneous culture in a } \\
\text { natural resources }\end{array}$ & $\begin{array}{l}\text { Usually not so homogeneous, } \\
\text { and mostly larger countries } \\
\text { with more resources, par- } \\
\text { ticularly in the case of the } \\
\text { USA }\end{array}$ \\
2. Decply ingrained sense of & More individualistic attitude
\end{tabular}

hierarchy, place, and obedience to authority

3. Prevalence of an ethic of conservation resulting in creating much from little

4. Guaranteed lifetime employment for most workers ${ }^{8}$

5. High work ethic, fast rising productivity ${ }^{9}$

6. Extensive pre- and postemployment orientation programmes $^{10}$

7. Emphasis is on quality ${ }^{11}$

8. Distinction between labour and management less important, because of excessive 'top-to-bottom' cross training; job exchange and career development planning are the norm, closing the gap between management and labour

9. Decisions reached through consensus and participation

10. QC programmes are perceived as a natural extension of training and education

11. Eagerly seeking workers' suggestions ${ }^{\text {i? }}$

12. Belief in capacity for responsibility of the worker. who seeks challenges and exercises self-direction and self-control wasting, illusions of 'abundance'

No such guarantees

Lower work ethic with sagging productivity

Very little or no orientation

Emphasis is on costs

Great distinction between management and labour, little or no employee training and development, therefore managers are more likely to see themselves as elite corps of decision-makers

Decisions made by relying on 'orders from authority', mostly excluding individual creative thinking ${ }^{12}$

QC programmes are a "new technique', viewed with scepticism and suspicion Restricting input of ideas from floor level

Belief in lack of responsibility, initiative and creativity of worker, who 'strongly needs outer direction'
Attitudes and habits of

\section{Steering committee (group 7)}

The QC concept includes a steering committee comprising representatives from all levels of management, whose function it is to establish $Q C$ policies (i.e. the type of problems QCs should consider analysing). The committee members could be described as 'policy specialists' who in-

itiate and later maintain the support of the organization.

\section{Advisory committee (group 8)}

The eighth group within the QC concept is the advisory committee. In brief, it comprises a group of technical experts, in contrast to the seventh group which represents a group of policy specialists. This advisory body consults on all technical matters encountered by the QCs. It must have an overview, to enable it to coordinate and advise individual QCs working on similar technical problems, or using identical technical components. Parts of solutions or 'stepping stones' including technical data from one QC may well be used by another QC, thus avoiding duplication of technically-related work. The committee members originate from all levels of technical management, including specialists from various departments within the company, such as cost-analysis experts, valueengineering specialists, statistical experts and engineers.

\section{Union officials (group 9)}

The ninth group, union officials, like management, has to be convinced that the QC concept will benefit everyone in the company. There is no point in introducing a QC programme if the union shows antagonism. Union officials should be invited to participate actively in the QC programme. There seem to be indications that labour relations in the USA are becoming much more collaborative. Many top union leaders see the future of collective bargaining more in the quality of worklife rather than just in higher wages.

\section{A process flow diagram (model) of the quality circle system}

The closed cycle of a QC system is shown in Figure 3. It represents a model of the QC process flow for one complete cycle. This model can be extremely useful since it shows the various interdependencies of all the groups involved (with the facilitator and steering committee in a central position) and how the QC system actually works. It can also be used as a tool for consultants or middle management during the process of preparing top management for the $\mathrm{QC}$ concept, facilitating the understanding of the process during the introductory phase (where the role to be played by each group is clearly indicated) and finally, the changes that would have to be introduced if certain problems arise. Use of this model will show the effects these problems (or changes) will have on certain groups, and the resulting interactions can be easily demonstrated and/or verified.

After a management decision to introduce the $\mathrm{QC}$ system has been made, the first step of the process flow then would be a recommendation of problems to the $\mathrm{QC}$ with input from seven sources or groups and from the QC members themselves. After the actual problem is selected, a thorough analysis follows, supported by technical staff and the advisory committee's technical experts (or specialists). The solution is then 'marketed' in a presentation to management, which is as brief, wellorganized and as comprehensive as possible. The recommendations are then reviewed and evaluated by middle management. Only under special circumstances (highly significant solutions), involving major changes in capital 

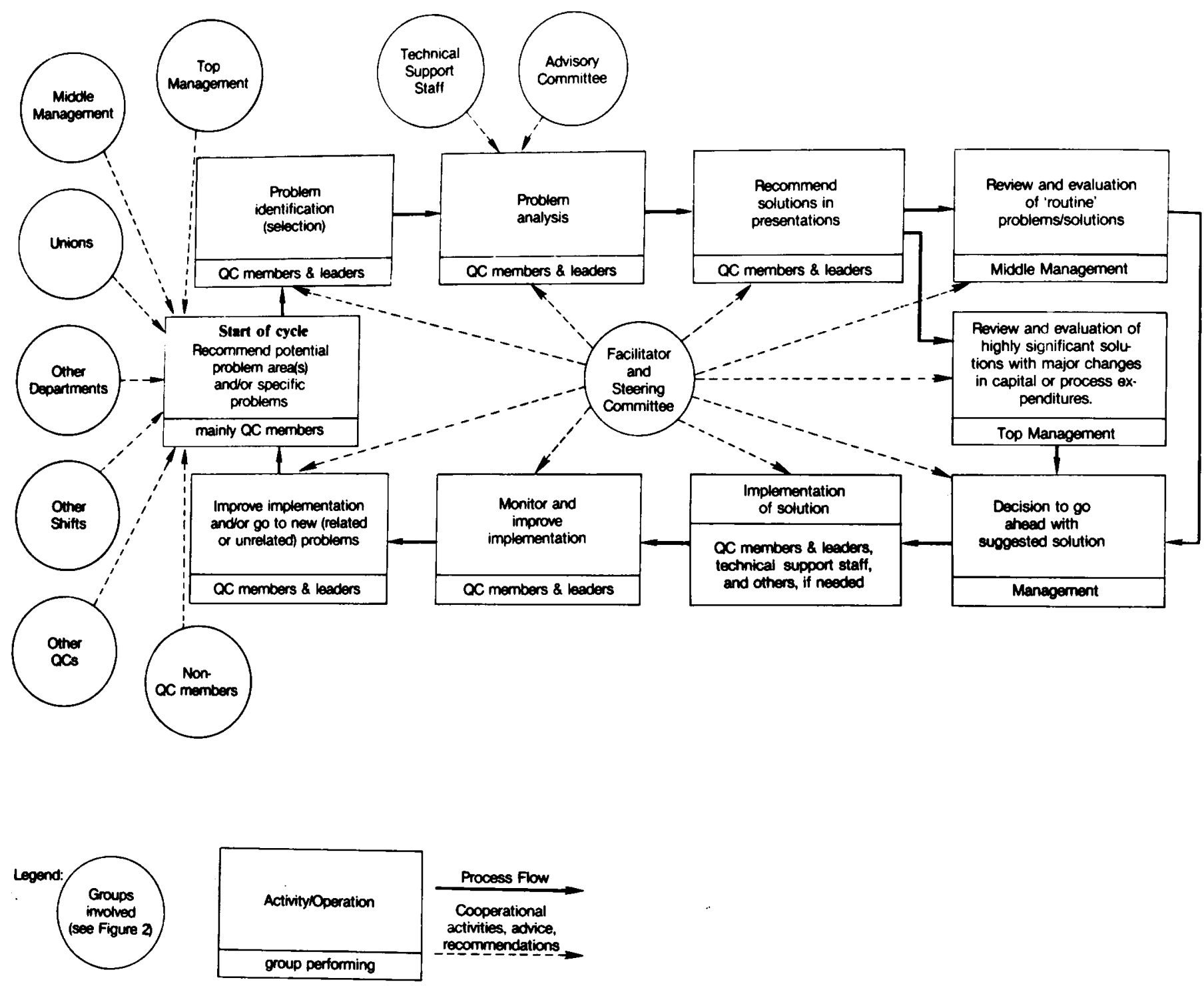

Figure 3 The closed-cycle model of a QC process flow

or process expenditures, is the QC presentation made to top management. This is normally followed by a decision to proceed as suggested, possibly with the inclusion of a few modifications or alterations. The original or modified suggestion is then implemented, monitored and improved, if necessary. The cycle is closed with the selection of a new problem, or very rarely, the reconsideration of a solution returned for improvement or change.

The circles in Figure 3 indicate the various groups involved with some input (see Figure 2), and the squares represent the activities/operations to be performed during the QC process cycle. The solid or dotted arrows show the direction of the process flow and that of the advisory, recommendational or cooperational inputs from the various groups to the QCs.

\section{Concluding remarks}

The successful implementation of QCs in a company can only take place if middle and top management fully understand the conditions necessary for the success of the QC programme.

The best-known Western companies that have benefited from this philosophy are Lockheed, Rolls-Royce, Hewlett-Packard, Ford and IBM. Ford strongly believe that their QC system was one of the most important reasons for their being able to increase their ability to compete with the Japanese.

In South Africa, organizations such as Armscor and Southern Cross Steel are already implementing similar systems. According to Spoelstra ${ }^{14}$ there is also reason to believe that the various systems that used to be 'Japanese only' are even better suited in South Africa, owing to the cultural make-up of its human resources, than in many other Western countries, and that these could be implemented with great success here.

\section{Bibllography}

1. GREGERMAN, I.B. 'Introduction to Quality Circles - An Approach to Participative Problem-Solving.' Ind. Manage., September/October, 1979, 21(5), p.21.

2. Anonymous. 'Japan to Sell Robot Factories.' Pretoria News, October 29, 1981

3. MURRAY, G. 'Robots Can Set You Free, Claim Japanese.' Pretoria News, November 3, 1981.

4. NOSOW, S. 'The First-Line Supervisor, the Linchpin in the Japanese Quality Control Circle.' Ind. Manage.,

January/February 1981, 23(1), p. 19.

5. HUTCHINS, D. 'QC Circles, An Introduction.' Ind. Commer. Training, (UK), January 1980, 12(1), p.11.

6. YAGER, E. 'Examining The Quality Control Circles.' Person- 
nel, October 1979, 58(10), p.682.

7. Anonymous. 'Organizing for Productivity.' Industry Week, February 1981, 20(3), p.45.

8. DRUCKER, P.F. 'The Price of Success, Japan Revisited.' Across the Board, August 1978, p.30.

9. HODGESON, J.D. 'The Wondrous World of Japan.' American Enterprise Institute, Washington, D.C., 1978.

10. TANAKA, H. 'The Japanese Method of Preparing Today's Graduate to Become Tomorrow's Manager,' Personnel, February 1980, p.109.
11. Anonymous. 'Japan's Managers Tell How Their System Works.' Fortune, November 1977, p.127.

12. ALBERT, R.G.'The Creative Mind.' Institute For Creative Problem Solving. State University College, Buffalo, N.Y., 1980, p.19.

13. WERTHER, W.B. 'Productivity Improvement Through People'. Ariz. Bus., February 1981, 28(2), p.14.

14. SPOELSTRA, H.I.J. Kulturele Determinante van Organisatoriese Doeltreffendheid in Suid-Afrika en Japan. Ongepubliseerde D.Com.-proefskrif, RAU, 1980, p.213. 